Becoming a European Homegrown Jihadist 



\section{Becoming a European Homegrown Jihadist}

A Multilevel Analysis of Involvement in the Dutch

Hofstadgroup, 2002-2005

Bart Schuurman 
Parts of this research were supported by grants from the Prins Bernhard Cultuurfonds and the Fulbright Visiting Scholar program.

Cover illustration: Ten years after the murder of Theo van Gogh by Mohammed Bouyeri, the bullet holes are still visible in the bicycle lane in front of Linnaeusstraat 22, Amsterdam. Source: Wikimedia Commons

Cover design: Coördesign, Leiden Lay-out: Crius Group, Hulshout

Amsterdam University Press English-language titles are distributed in the US and Canada by the University of Chicago Press.

$\begin{array}{ll}\text { ISBN } & 978946298693 \text { o } \\ \text { e-ISBN } & 9789048538300 \text { (pdf) } \\ \text { DOI } & 10.5117 / 9789462986930 \\ \text { NUR } & 686 / 717 / 754\end{array}$

(C) Bart Schuurman / Amsterdam University Press B.V., Amsterdam 2018

All rights reserved. Without limiting the rights under copyright reserved above, no part of this book may be reproduced, stored in or introduced into a retrieval system, or transmitted, in any form or by any means (electronic, mechanical, photocopying, recording or otherwise) without the written permission of both the copyright owner and the author of the book. 
For Marlies, Willem \& Claire 
